KALAMATIKA Jurnal Pendidikan Matematika

Volume 3, No. 1, April 2018, hal. 51-62

$\mathbf{K} / \mathbf{L} \triangle \mathbf{M} / \mathbf{T} \mid \mathbf{K} \wedge$

\title{
IDENTIFIKASI KESULITAN BELAJAR MAHASISWA MELALUI MODEL PROJECT BASED LEARNING
}

\author{
Siska Firmasari ${ }^{1}$, Dina P. D. Santi ${ }^{2}$ \\ ${ }^{1}$ Universitas Swadaya Gunung Jati Cirebon \\ siskafs@fkip-unswagati.ac.id \\ ${ }^{2}$ Universitas Swadaya Gunung Jati Cirebon \\ dinapratiwids@fkip-unswagati.ac.id
}

\begin{abstract}
ABSTRAK
Tujuan dari penelitian ini adalah untuk mengetahui kesulitan belajar yang dialami mahasiswa tingkat III program studi Pendidikan Matematika selama pelaksanaan Project Based Learning (PjBL) pada mata kuliah Evaluasi Proses dan Hasil Pembelajaran Matematika. Penelitian ini menggunakan metode deskriptif dengan pendekatan kualitatif karena relevan dilihat dari proses awal sampai tersusunnya produk akhir, dan instrumen penelitian yang digunakan berupa lembar wawancara. Sampel penelitian adalah 68 orang mahasiswa tingkat III Program Studi Pendidikan Matematika FKIP Universitas Swadaya Gunung Jati Cirebon. Penelitian dilakukan dalam kurun waktu Maret - Juli 2016. Berdasarkan hasil penelitian dapat disimpulkan bahwa kesulitan belajar mahasiswa selama pelaksanaan Project Based Learning disebabkan oleh faktor internal yaitu kurangnya motivasi, yang tampak dari minimnya mahasiswa dalam membaca dan mencari berbagai referensi terkait materi, mereka hanya menggantungkan sumber belajar dari satu buku acuan saja yang digunakan saat perkuliahan. Hal tersebut berdampak pada kurangnya pemahaman dalam mempelajari materi kualitas instrumen evaluasi yang terlihat dari kesulitan dalam mengelompokkan soal-soal tes evaluasi berdasarkan Taksonomi Bloom dan menyusun pedoman penskoran, menggunakan rumus validitas, reliabilitas, daya pembeda, dan indeks kesukaran untuk menentukan kualitas instrumen, serta kesulitan dalam menyusun produk akhir.
\end{abstract}

Kata Kunci: Kesulitan Belajar, Tes Penilaian, Project Based Learning

\begin{abstract}
The purpose of this study was to know the learning difficulties experienced by third grade students of Mathematics Education Study Program during Project Based Learning (PjBL) implementation on Evaluation of Mathematics' Learning Process and Result. This research used descriptive method with qualitative approach because it is relevant from the initial process to the final product, and research instrument used is in the form of interview sheet. The sample of this research is 68 third grade students of Mathematics Education Study Program of Faculty of Teaching and Educational Sciences, University of Swadaya Gunung Jati Cirebon. The study was conducted in the period of March - July 2016. Based on the results of this study it can be concluded that students' learning difficulties during the implementation of Project Based Learning caused by internal factors, that is lack of motivation, which can be seen from the lack of students in reading and looking for various references related to the material, they rely on one reference book only that used during lectures. This resulted to the lack of understanding in learning the Evaluation Instruments' Quality which can be seen from the difficulty in classifying evaluation test questions based on Bloom's Taxonomy and arranging scoring
\end{abstract}


guidelines, using validity formula, reliability, item discrimination, and index of difficulty to determine instrument quality, and difficulty in accomplishing the final product.

Keywords: Learning Difficulties, Assessment Test, Project Based Learning

Format Sitasi: Firmasari, S., \& Santi, D.P.D. (2017). Identifikasi Kesulitan Belajar Mahasiswa Melalui Model Project Based Learning. KALAMATIKA Jurnal Pendidikan Matematika, 3(1), 51-62.

Penyerahan Naskah: 7 Oktober 2018 || Revisi: 28 Februari 2018 || Diterima: 1 Maret 2018.

\section{PENDAHULUAN}

Belajar merupakan sebuah proses perubahan perilaku yang disebabkan oleh adanya interaksi dengan lingkungan sekitar. Syarifuddin (2011) berpendapat bahwa "belajar adalah kegiatan yang dilakukan orang secara maksimal untuk dapat menguasai atau memperoleh sesuatu". Artinya, dalam proses belajar diperlukan suatu usaha untuk mewujudkan tujuan yang dicita-citakan. Sedangkan menurut Nidawati (2011), belajar merupakan proses yang melibatkan ranah kognitif, afektif, dan psikomotorik yang kompleks. Dengan demikian, dapat disimpulkan bahwa belajar dapat terjadi jika ada tujuan yang hendak dicapai, seperti perubahan perilaku yang menyangkut ranah kognitif, afektif, dan psikomotorik.

Untuk mencapai tujuan belajar ada kalanya ditemukan berbagai macam kesulitan. Hal ini juga dialami oleh mahasiswa sebagai subjek belajar mandiri. Menurut Ma'rifah (2017) ada tiga indikator kesulitan belajar mahasiswa yakni faktor internal (fisiologis dan psikologis), eksternal (lingkungan sosial dan nonsosial), dan perilaku. Salah satu faktor yang cukup besar mempengaruhi kemampuan belajar mahasiswa adalah faktor internal. Hal ini sesuai dengan hasil penelitian yang dilakukan oleh Kunhardianto \& Dewi (2016) yang menyatakan bahwa faktor internal kesulitan belajar yang dihadapi siswa dengan kenaikan prestasi belajar saling berbanding terbalik. Pernyataan tersebut diperkuat oleh hasil penelitian Januarti, Imran, Supriadi (2015) yang mengemukakan bahwa adanya ketidakmampuan siswa dalam menampilkan unjuk kerja merupakan salah satu faktor internal kesulitan belajar.

Fakta di lapangan yang ditemukan dosen pengampu berdasarkan hasil ujian akhir, ditemukan faktor internal kesulitan belajar mahasiswa program studi Pendidikan Matematika pada mata kuliah Evaluasi Proses dan Hasil Pembelajaran Matematika adalah menyusun dan menganalisis kualitas instrumen evaluasi. Hal ini diperkuat dari hasil wawancara dengan 
mahasiswa tingkat III yang telah mengontrak mata kuliah Evaluasi Proses dan Hasil Pembelajaran Matematika yang mengungkapkan bahwa $\geq 50 \%$ mahasiswa kebingungan saat harus menyusun soal-soal evaluasi yang disesuaikan dengan kriteria soal, tujuan pembelajaran, kesesuaian batasan materi, serta menyimpulkan bagaimana kualitas instrumen tes setelah hasil penilaian diperoleh. Bagi mahasiswa calon guru, kemampuan menyusun instrumen tes dan menganalisis kualitas instrumen evaluasi tersebut sangat dibutuhkan, karena berpengaruh pula pada saat pengerjaan skripsi.

Salah satu cara mengidentifikasi secara jelas dan mendalam kesulitan belajar tersebut menurut Yenni (2016) adalah melalui pemilihan model dan strategi pembelajaran yang tepat. Larmer et al (2015) menjelaskan bahwa model pembelajaran yang memberikan kesempatan kepada mahasiswa untuk membangun kualitas belajar mereka dengan cara mempelajari isi pembelajaran sesuai kemampuan akademis dan memahami bagaimana isi pembelajaran tersebut terjadi dalam kehidupan sehari-hari adalah model Project Based Learning (PjBL). Ditambahkan oleh Patton (2012), PjBL mengajak mahasiswa merancang, merencanakan, dan melaksanakan proyek sampai dengan menghasilkan luaran yang dipamerkan kepada khalayak umum, dimana luaran tersebut ditampilkan dalam bentuk produk, publikasi, atau presentasi. Sehingga melalui PjBL, dosen akan jelas mengidentifikasi berbagai kesulitan belajar yang dialami mahasiswa melalui setiap tahapan pengerjaan proyek, baik individual maupun kelompok. Diharapkan pada akhirnya semua kesulitan belajar tersebut dapat teratasi.

PjBL yang diterapkan pada penelitian ini menugaskan mahasiswa untuk terjun langsung ke sekolah mengimplementasikan teori mengenai kualitas instrumen evaluasi. Tahapan pengerjaan tugasnya mengacu pada enam sintaks yang dijelaskan oleh Sumarni (2013) yaitu, (1) Mulai Dengan Pertanyaan Penting, (2) Desain Rencana Proyek, (3) Menyusun Jadwal Kegiatan Proyek, (4) Memantau Mahasiswa dan Kemajuan Proyek, (5) Menilai Hasil Keluaran Proyek, (6) Evaluasi Pengalaman Mahasiswa. Ditambahkan oleh Tamim \& Grant (2013), PjBl menekankan pembelajaran berpusat pada mahasiswa dan penilaian dilakukan menggunakan rubrik yang dibagikan kepada mahasiswa sebelum proyek dikerjakan untuk memperjelas kualitas yang diharapkan dari produk akhir. Masih menurut mereka, penilaian diperoleh pula dari keterampilan mahasiswa serta kontribusi mahasiswa baik secara individu maupun dalam kelompok selama sintaks PjBL dilakukan. 
PjBL dalam mata kuliah Evaluasi Proses dan Hasil Pembelajaran Matematika, menjadikan mahasiswa mampu menyusun soal-soal instrumen evaluasi secara mandiri sesuai dengan indikator Bloom (C1 - C6) dan kondisi siswa di sekolah, serta menentukan kualitas dari instrumen evaluasi tersebut. Selain itu mahasiswa diharapkan mampu mengatasi kesulitan ketika menemukan permasalahan saat uji coba soal-soal instrumen evaluasi yang dilakukan di sekolah. Dengan demikian mahasiswa memiliki pengalaman sehingga mempermudah pada saat penyusunan skripsi, dan mengetahui prosedur pelaksanaan evaluasi di sekolah sebagai bekal saat mereka menjadi guru. Akibatnya, kemampuan mereka dalam mengevaluasi instrumen soal dapat meningkat.

Berdasarkan uraian di atas, maka tujuan penelitian ini adalah mengetahui kesulitankesulitan belajar yang dialami mahasiswa tingkat III program studi Pendidikan Matematika pada mata kuliah Evaluasi Proses dan Hasil Pembelajaran Matematika selama pelaksanaan Project Based Learning (PjBL). Pada akhirnya penelitian ini diharapkan dapat bermanfaat sebagai referensi bagi pengampu mata kuliah Evaluasi Proses dan Hasil Pembelajaran Matematika untuk memberikan tindakan yang sesuai bagi mahasiswa sehingga pembelajaran dapat mencapai tujuannya dan mahasiswa memperoleh hasil akhir yang memuaskan, serta bermanfaat pula bagi peneliti lain yang ingin mengidentifikasi kesulitan belajar mahasiswa melalui Project Based Learning.

\section{METODE PENELITIAN}

Penelitian ini digolongkan dalam jenis penelitian deskriptif dengan pendekatan kualitatif, karena penelitian ini ditujukan untuk mengidentifikasi dan mendeskripsikan secara jelas kesulitan belajar yang dialami mahasiswa pada materi kualitas instrumen evaluasi langsung dari sumbernya yaitu mahasiswa selama pengerjaan proyek yang ditugaskan, mulai dari perencanaan sampai dengan produk yang dihasilkan dan data penelitian yang diperoleh berupa hasil wawancara. Hal tersebut senada dengan penelitian yang dilakukan oleh Subandi (2011), dimana penelitian yang digunakan merupakan penelitian deskriptif dengan pendekatan kualitatif, dimana penelitiannya mendeskripsikan tentang suatu kegiatan seni pertunjukan melalui alat pengumpul data salah satunya adalah lembar wawancara. Pendekatan kualitatif dapat dikatakan sebagai sebuah pendekatan yang menjelaskan tentang suatu peristiwa, tindakan, atau pengalaman hidup yang terhubung (Susila, 2011). Jadi penelitian bersifat alamiah semua bersumber dari kondisi nyata di lapangan. 
Penelitian dilakukan pada semester genap tahun akademik 2015/2016 bulan Maret - Juli 2016. Populasi dalam penelitian ini adalah seluruh mahasiswa tingkat III semester enam program studi Pendidikan Matematika FKIP Unswagati Cirebon tahun akademik 2015/2016, sedangkan sampel yang dipilih yaitu 68 mahasiswa dari tiga kelas. Pemilihan sampel tersebut dilakukan secara purposive didasarkan pada hasil pengamatan peneliti bahwa ketiga kelas memiliki tingkat kognitif dan tingkat keaktifan secara rata-rata lebih rendah dibandingkan kelaskelas lainnya.

Penelitian diawali dengan pengelompokan mahasiswa ke dalam empat kelompok dalam satu kelas sampel. Selanjutnya mahasiswa sebagai objek penelitian mengerjakan proyek secara berkelompok yang diberikan oleh peneliti melalui lima kegiatan. Pada kegiatan pertama, mahasiswa diminta menjawab pertanyaan penuntun mengenai bagaimana menyusun soal-soal tes evaluasi dilengkapi kunci jawaban dan rubrik penilaian agar mendapatkan soal-soal yang berkualitas. Dengan pertanyaan tersebut mahasiswa menggali konsep apa yang sedang dikaji. Kegiatan kedua, mahasiswa menyusun instrumen tes (instrumen evaluasi) disesuaikan dengan tahapan kognitif dari Bloom yakni pengetahuan (C1), pemahaman (C2), penerapan (C3), analisis (C4), sintesis (C5), dan evaluasi (C6), serta kemampuan matematis. Instrumen tes yang disusun oleh mereka tidak dapat langsung digunakan namun dalam proses penyusunannya dilakukan proses pembimbingan dengan peneliti, agar soal yang disusun sesuai dengan kriteria pada rubrik penilaian (seperti kesesuaian dengan silabus dan materi yang diajarkan di sekolah). Kegiatan ketiga, mahasiswa melakukan penyelidikan melalui kegiatan yang dilakukan di sekolah untuk mendapatkan jawaban mengenai kualitas instrumen tes yang telah diuji coba yang disesuaikan dengan tujuan pembuatan tes. Kegiatan keempat, mahasiswa saling berdiskusi dan bekerjasama dalam memahami dan menemukan penyelesaian mengenai kualitas instrumen tes berdasarkan hasil penyelidikan. Pada kegiatan kelima, mahasiswa menyusun produk dari proyeknya berupa laporan berbentuk portofolio, yang selanjutnya dipresentasikan, dan diakhiri kegiatan wawancara dengan peneliti. Selama pengerjaan proyek, mahasiswa selalu berdiskusi dengan peneliti, sehingga tidak menyalahi langkah-langkah Project Based Learning yang telah ditetapkan.

Instrumen yang digunakan dalam penelitian ini adalah lembar wawancara. Identifikasi kesulitan belajar dilakukan terhadap hasil wawancara dengan mahasiswa. Wawancara terbuka dilakukan dengan daftar pertanyaan yang terfokus pada kesulitan-kesulitan belajar yang 
dihadapi mahasiswa terkait dengan pelaksanaan Project Based Learning untuk materi kualitas instrumen evaluasi. Wawancara dimulai dari pertanyaan seputar pembuatan soal, tindak lanjut uji coba soal ke sekolah, pengkoreksian terhadap lembar jawab siswa, olah data instrumen evaluasi, diakhiri dengan produk yang diperoleh berupa laporan tertulis dan presentasi.

\section{HASIL DAN PEMBAHASAN}

\section{Kesulitan Mahasiswa Selama Pelaksanaan Project Based Learning}

Kesulitan belajar yang dialami mahasiswa dalam materi kualitas instrumen evaluasi mulai tampak dari tahapan awal pelaksanaan Project Based Learning. Untuk lebih memperjelas kegiatan apa saja yang dilakukan mahasiswa dalam mengimplementasikan enam sintaks Project Based Learning dan kesulitan yang dihadapi, berikut ditampilkan uraiannya pada Tabel 1.

Tabel 1. Kegiatan dan Kesulitan Mahasiswa dalam Pelaksanaan PjBL

\begin{tabular}{|c|c|c|}
\hline No. & Kegiatan & Kesulitan yang Ditemukan \\
\hline 1. & $\begin{array}{l}\text { Mahasiswa diberikan pertanyaan tentang bagaimana } \\
\text { menyusun soal-soal evaluasi dilengkapi kunci jawaban dan } \\
\text { rubrik penilaian agar mendapatkan soal-soal yang } \\
\text { berkualitas. Dengan pertanyaan tersebut mahasiswa menggali } \\
\text { konsep apa yang sedang dikaji. }\end{array}$ & Tidak ditemukan kesulitan \\
\hline 2. & $\begin{array}{l}\text { Untuk mendapatkan pengalaman belajar langsung di } \\
\text { masyarakat, mahasiswa diminta untuk mendesain soal-soal } \\
\text { tes evaluasi dilengkapi dengan kunci jawaban dan rubrik } \\
\text { penilaian untuk diujicobakan ke sekolah. }\end{array}$ & 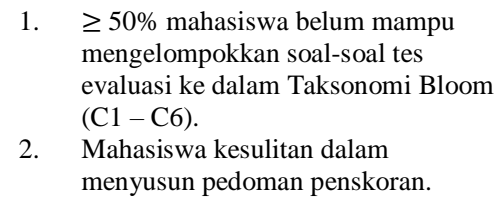 \\
\hline 3. & $\begin{array}{l}\text { Mahasiswa melakukan penyelidikan melalui kegiatan yang } \\
\text { dilakukan di sekolah untuk mendapatkan jawaban mengenai } \\
\text { kualitas instrumen tes yang telah diuji coba dan disesuaikan } \\
\text { dengan tujuan pembuatan tes. }\end{array}$ & Tidak ditemukan kesulitan \\
\hline 4. & $\begin{array}{l}\text { Mahasiswa saling berdiskusi dan bekerjasama dalam } \\
\text { memahami dan memecahkan masalah mengenai kualitas } \\
\text { instrumen tes berdasarkan hasil penyelidikan. }\end{array}$ & $\begin{array}{l}\text { Mahasiswa kesulitan menggunakan rumus } \\
\text { validitas, reliabilitas, daya pembeda, dan } \\
\text { indeks kesukaran. }\end{array}$ \\
\hline 5. & $\begin{array}{l}\text { Mahasiswa menyusun produk dari proyeknya berupa laporan } \\
\text { berbentuk portofolio, yang selanjutnya dipresentasikan, dan } \\
\text { diakhiri kegiatan wawancara dengan peneliti. }\end{array}$ & $\begin{array}{l}\text { Mahasiswa masih melakukan kesalahan } \\
\text { dalam penulisan laporan dilihat dari tata } \\
\text { tulis dan bahasa. }\end{array}$ \\
\hline
\end{tabular}

Kesulitan-kesulitan yang dialami mahasiswa dipertegas pula melalui hasil wawancara yang dilakukan peneliti. Adapun hasil wawancara yang dimaksud memberikan hasil sebagai berikut.

Keraguan muncul pada mahasiswa pada saat mengelompokkan soal-soal instrumen evaluasi yang telah disusun untuk disesuaikan dengan tahapan kognitif Bloom siswa di sekolah yang akan dituju. Keraguan tersebut mereka utarakan dikarenakan keterbatasan mereka dalam memahami tahapan kognitif Bloom, dan menurut mereka tidak semua tahapan kognitif Bloom dapat diterapkan untuk menyusun soal-soal evaluasi pada materi pelajaran matematika di 
sekolah menengah. Sehingga beberapa kelompok hanya mengambil beberapa tahapan Bloom saja untuk diimplementasikan dalam soal-soal evaluasi.

Mahasiswa kebingungan pada saat menyusun pedoman penskoran untuk soal-soal evaluasi yang sudah disusun. Hal ini disampaikan dikarenakan mereka kesulitan menyesuaikan berapa skor yang tepat untuk setiap tahapan jawaban siswa, sesuai tidaknya skor yang tertera dengan kemampuan siswa dalam menjawab soal, dan berapa skor yang sesuai untuk setiap butir soal.

Kesulitan lain ditemukan pada saat menggunakan rumus untuk menentukan kualitas instrumen evaluasi. Mereka mengutarakan bahwa ketika melakukan perhitungan akhir, kurang memahami komponen-komponen yang harus dimasukkan dalam rumus perhitungan kualitas instrumen evaluasi untuk soal bentuk pilihan ganda dan uraian. Sehingga berdampak kesalahan pada penentuan kualitas instrumen evaluasi (validitas, reliabilitas, daya pembeda, dan indeks kesukaran).

Kesulitanpun ditemukan oleh mahasiswa ketika pengumpulan produk hasil Project Based Learning berupa laporan tertulis. Format laporan yang sudah disampaikan pada pertemuan awal penugasan, sudah mampu diterapkan dengan baik hanya saja tata tulis dan bahasa yang digunakan masih ditemukan beberapa kesalahan, diantaranya mahasiswa sulit menyusun bahasa formal yang sesuai dengan format laporan akhir sehingga beberapa bahasa nonformal masih ditemukan, ukuran dan jenis hurup yang tidak sesuai, penggunaan spasi yang keliru, serta hasil ketikan yang tidak rata untuk sisi kiri dan kanan paragraf. Menurut mahasiswa hal tersebut diakibatkan karena mereka tidak terbiasa menyusun laporan hasil kegiatan.

\section{Pembahasan}

Kesulitan yang dihadapi mahasiswa, seperti mengelompokkan soal-soal tes evaluasi sesuai dengan Taksonomi Bloom, menyusun pedoman penskoran, menggunakan rumus validitas, reliabilitas, indeks kesukaran, dan daya pembeda, dan menyusun laporan akhir sesuai dengan kaidah penulisan, disebabkan oleh kurangnya motivasi yang timbul dalam diri mahasiswa. Hal tersebut tampak dari keengganan mahasiswa membaca dan mencari referensi lain selain buku yang digunakan saat perkuliahan terkait materi kualitas instrumen evaluasi. Mereka hanya mengandalkan satu buku saja dan jika dalam buku tersebut tidak ditemukan pemecahan dari permasalahan mereka, maka mereka langsung bertanya pada dosen pengampu 
mata kuliah Evaluasi Proses dan Hasil Pembelajaran Matematika. Keengganan dalam membaca dan mencari referensi menyebabkan informasi yang mereka peroleh juga terbatas.

Motivasi merupakan faktor internal kesulitan belajar yang dialami mahasiswa. Motivasi yang muncul dalam diri mahasiswa akan sulit untuk ditingkatkan jika dari diri mahasiswa itu sendiri tidak ada keinginan untuk berubah. Mahasiswa harus mampu melawan rasa malas dan acuh. Karena mahasiswa sebagai pembelajar mandiri tidak boleh membatasi diri dengan hanya mempelajari satu buku referensi saja dan mengandalkan dosennya untuk mentransfer berbagai ilmu dan pengetahuan. Mahasiswa harus mengembangkan diri dengan mencari dan menemukan berbagai referensi agar informasi yang mereka perlukan dapat mereka temukan sendiri namun tetap berpegang pada konsep. Dosen bertindak sebagai pemberi arahan dan bimbingan ketika informasi yang diterima mahasiswa ada ketidak sesuaian dengan konsep. Seperti yang diungkapkan oleh The Higher Education Academy (2012) bahwa tanggung jawab untuk belajar di pendidikan tinggi terletak pada mahasiswa, dengan dibantu arahan oleh pengajar, ditentukan oleh batas dan tujuan program perkuliahan.

Lai (2011) mengatakan bahwa motivasi merupakan keterkaitan erat antara persepsi, nilai, minat, dan tindakan. Jika dihubungkan dengan hasil penelitian, maka diperoleh satu kesimpulan bahwa mahasiswa mempersepsikan dirinya selayak siswa sekolah pada umumnya yang masih berpegang pada buku teks yang direkomendasikan oleh guru saja, dan bertindak dengan hanya mencari informasi terkait kesulitan yang mereka temui selama pengerjaan tugas pada dosen pengampu. Hal ini mengakibatkan ruang gerak mereka untuk mencari informasi menjadi sangat terbatas.

Namun mahasiswa mengakui dalam menyelesaikan proyek yang diberikan ditemukan berbagai pengetahuan dan pengalaman baru. Berdasarkan hasil wawancara terhadap mahasiswa, diperoleh kesimpulan lain bahwa melalui pembelajaran dengan model penugasan seperti Project Based Learning memberikan kesan tersendiri dan belajar mandiri itu ternyata menyenangkan. Mereka mampu menyelesaikan berbagai permasalahan terkait kekompakan dalam belajar kelompok, suasana belajar yang lebih menyenangkan karena permasalahan yang ditemukan dapat dipecahkan bersama-sama, memperoleh pengalaman belajar langsung dan mengetahui kondisi nyata di sekolah dengan mempraktekkan teori yang diperoleh. Hal tersebut berdampak pada semangat belajar yang meningkat. Hal yang senada dikemukakan pula oleh Yalcin, A., et al (2009) dari hasil wawancara terhadap siswa di akhir penelitian mereka, menunjukkan bahwa 
siswa mengalami berbagai kesulitan selama pengerjaan proyek yang diberikan oleh guru mereka, tetapi hal tersebut justru menunjukkan adanya peningkatan pengetahuan siswa yang diperoleh dari pemecahan masalah yang mereka hadapi dan membuat kegiatan belajar menjadi lebih baik.

\section{KESIMPULAN}

Berdasarkan identifikasi terhadap kesulitan belajar yang dialami mahasiswa tingkat III selama pelaksanaan Project Based Learning pada mata kuliah Evaluasi Proses dan Hasil Pembelajaran Matematika, dapat disimpulkan bahwa mereka mengalami kesulitan dalam menyusun soal-soal tes evaluasi sesuai dengan tahapan Taksonomi Bloom, menyusun pedoman penskoran, menggunakan rumus validitas, reliabilitas, indeks kesukaran, dan daya pembeda, serta menyusun laporan akhir sesuai dengan kaidah penulisan.

\section{REKOMENDASI}

Rekomendasi yang diberikan oleh peneliti adalah sebagai berikut.

1. Identifikasi terhadap kesulitan belajar mahasiswa melalui model Project Based Learning pada mata kuliah Evaluasi Proses dan Hasil Pembelajaran Matematika sebaiknya ditelaah lebih lanjut dan diberikan solusi sehubungan dengan kelancaran pengerjaan proyek, tidak hanya pada mata kuliah ini tetapi juga menyangkut kelancaran pengerjaan skripsi mahasiswa nantinya.

2. Mata kuliah Evaluasi Proses dan Hasil Pembelajaran Matematika khususnya, dan mata kuliah lain pada umumnya, disarankan agar menggunakan metode pembelajaran Project Based Learning agar materi dipahami mahasiswa secara mandiri, kreativitas mahasiswa dapat berkembang, terbangunnya keaktifan mahasiswa selama pembelajaran, serta dapat mengajarkan pentingnya kerjasama dalam kelompok.

3. Pada implementasi Project Based Learning disarankan agar senantiasa diadakan konsultasi dua arah antara mahasiswa dan dosen pengampu mata kuliah sehingga kesulitan-kesulitan yang terjadi tidak menimbulkan efek negatif pada penyelesaian produk akhir. 


\section{REFERENSI}

Higher Education Academy. (2014). Independent Learning, (Online), (https://www.heacademy.ac.uk/system/files/resources/independent_learning.pdf)

Januarti, A., Imran., \& Supriadi. (2015). Analisis Faktor Penyebab Kesulitan Belajar Siswa pada Mata Pelajaran Sosiologi. Jurnal Pendidikan dan Pembelajaran, 4(11), 1-14.

Kunhardianto, H., \& Dewi, R.M. (2016). Pengaruh Faktor Internal dan Eksternal Kesulitan Belajar terhadap Prestasi Belajar Ekonomi pada Siswa Kelas XI IPS SMA Negeri 1 Ngoro Mojokerto. Jurnal Pendidikan Ekonomi, 4(1), 1-9.

Lai, E.R. (2011). Motivation: A literature review. Inggris: Pearson

Larmer, J., Mergendoller, J., \& Boss, S. (2015). Setting the Standard for Project Based Learning (A Proven Approach to Rigorous Classroom Instruction). United States of America: ASCD.

Ma'rifah, D.R. (2017). Diagnosis Kesulitan Belajar Mahasiswa Pada Mata Kuliah Perkembangan Peserta Didik. Jurnal Pendidikan Biologi Indonesia, 3(1), 88-94. https://doi.org/10.22219/jpbi.v3i1.4056

Nidawati. (2013). Belajar dalam Perspektif Psikologi dan Agama. Jurnal Pionir, 1(1), 13-28.

Patton, A. (2012). Work That Matters: The Teacher's Guide to Project Based Learning. San Diego: Paul Hamlyn Foundation.

Subandi. (2011). Deskripsi Kualitatif sebagai Satu Metode dalam Penelitian Pertunjukan. Jurnal Harmonia, 11(2), 173-179.

Sumarni, W. (2013). The Strengths and Weaknesses of the Implementation of Project Based Learning: A Review. International Journal of Science and Research (IJSR), 4(3), 478483.

Susila, I. (2015). Pendekatan Kualitatif untuk Riset Pemasaran dan Pengukuran Kinerja Bisnis. Benefit Jurnal Manajemen dan Bisnis, 19(1), 12-23. 
Syarifuddin, A. (2011). Penerapan Model Pembelajaran Cooperative Belajar dan Faktor-Faktor yang Mempengaruhinya. Jurnal Ta'dib, 16(1), 113-136.

Tamim \& Grant. (2013). Definitions and Uses: Case Study of Teachers Implementing Projectbased Learning. Interdisciplinary Journal of Problem-based Learning, 7(2), 74-91. http://dx.doi.org/10.7771/1541-5015.1323

Yalcin, S.A., Turgut, U., Buyukkasap, E. (2009). The Effect of Project Based Learning on Science Undergraduates learning of Electricity, Attitude Towards Physics and Scientific Process Skills. International Online Journal of Educational Sciences, 1(1), 82-100.

Yenni, Y. (2016). Pengaruh Model Pembelajaran Learning Cycle Terhadap Kemampuan Pemahaman dan Koneksi Matematis Siswa SMP. KALAMATIKA Jurnal Pendidikan Matematika, 1(1), 71-83. 
